\title{
Triggering Economic Growth:Trade Liberalization as the Prominent Factor in Less-developed Countries
}

\author{
Mohsen Mohaghegh (Corresponding author) \\ Department of Economics, Ohio State University, USA \\ E-mail: mohaghegh.1@ osu.edu \\ A. S. Valipour \\ Department of Economics, Ohio State University, USA \\ E-mail: setayeshvalipour.1@osu.edu
}

Received: April 4, 2021 Accepted: April 29, $2021 \quad$ Published: May 12, 2021

doi:10.5296/ber.v11i2.18491ＵRL: https://doi.org/10.5296/ber.v11i2.18491

\begin{abstract}
Numerous theoretical and empirical studies have investigated the role of financial development, human capital accumulation, and trade liberalization on economic growth. Their findings, however, have been inconclusive as to which of these factors' implementation should policy makers prioritize. We construct a panel of more than 160 'developed', 'developing' and 'less-developed' countries between 1965 and 2017 to address this issue. We use non-stationary dynamic panel estimations to argue that quantitative effects of these factors depend on national income levels. Even though developed countries benefit the most from investing in their human capital and developing countries gain more by improving their financial institutions, our results show that both financial development and human capital are relatively ineffective in less developed countries. Nonetheless, trade liberalization has a stronger impact on GDP growth in these economies than in developing and developed countries.
\end{abstract}

Keywords: Economic growth, Trade liberalization, Human capital, Financial development, Non-stationary panels, Economic development

\section{Introduction}

This paper attempts to identify policies that are more effective in increasing economic output, particularly in less developed countries (LDCs). This is a fundamental question in development economics; specially as policy makers need to allocate their limited resources so 
to implement policies that break the poverty trap and to improve standard of living in their countries. Previous studies have established that financial development, human capital, and trade liberalization boost economic growth. However, despite the multitude of studies, the literature is far from a consensus about effective policies for different stages of development.

In this paper, we show that although all factors have a long-run positive impact on aggregate output in all countries, they have varying impacts in different development stages (Note 1). These differences not only explain some seemingly contradictory findings of empirical investigations, but can also be of significant importance for policy makers specially in LDCs where prioritizing over alternative options given very limited resources is critical. Our estimations show that financial and human capital development, though powerful in developed and developing countries, do not seem to be major drivers of economic growth in LDCs. Instead, trade liberalization can be a quantitatively more impactful solution in LDCs.

Romer (1990) in his seminal paper highlights the importance of human capital in standard growth models. Since then, several theoretical bases have been proposed to explain how human capital increases economic output (Aghion \& Howitt, 1992; Acemoglu, 1996). However, empirical results have been mixed in nature. Many have confirmed a positive relationship between country's GDP growth and its level of human capital level (Barro, 1991; Mankiw, Romer, \& Weil, 1992). But, some found weak (or no) links between human capital and output growth (Benhabib \& Spiegel, 1994; Bils \& Klenow, 2000).

In addition, after Hall \& Jones (1999) showed that human capital explains only a fraction of the differences between output per capita across countries, search for other possible economic factors was intensified. However, the two major additional factors identified by researchers, financial development and trade liberalization, also led to similar mixed and sometimes contradictory empirical findings.

McKinnon (1973) and Shaw (1973) are the first to point out that a free flow of capital leads to economic growth. A main mechanism through which financial development enhances economic growth is the allocative role of the financial markets. A more developed financial market efficiently allocates available funds to most productive projects, which improves marginal product of capital. Additionally, an improvement in the efficiency of capital allocation in the market affects capital formation rate as it changes the savings behavior of individuals (Levine, 1997).

Among others, King and Levine (1993), and Levine, Loayza, \& Beck (2000) empirically confirm a positive long-run relationship between proxies of financial development and economic growth. However, further investigation showed that the magnitude of such effects as well as mechanisms through which they affect growth substantially varies across countries (Shaker-Akhtekhane, 2019; Shaker-Akhtekhane, 2020; Narayan \& Narayan, 2013; Ductor \& Grechyna, 2015). Some even argued that financial development up to a threshold is beneficial for economic growth but beyond that would be detrimental (Law and Singh, 2014).

Similarly, a substantial literature has been developed on how trade affects economic growth. Various mechanisms are proposed for a positive relationship between free trade and an 
increase in the aggregate output (e.g. Rivera-Batiz and Romer (1991) and Wacziarg and Welch (2008)). However, in an influential paper, Rodriguez and Rodrik (1999) showed that the impact of trade liberalization on economic growth is not as robust.

We contribute to this strand of literature by providing a potential approach that can reconcile some of these empirical findings. We use data from more than 160 countries and divide them to three panels of "developed", "developing", and "less developed" countries. We use non-stationary panel data estimation techniques to compare the quantitative effects of human capital, financial development, and trade openness on output in each panel. Our premise is that these effects are different in different stages of economic development. Therefore, we expect the relative coefficients to vary across panels.

After establishing the existence of a long-run relationship between variables through panel cointegration tests, we use FMOLS and DOLS estimators to compare the relative importance of human capital, financial development, and trade liberalization in all three panels. We find that human capital is noticeably more effective in developed economies while developing countries gain the most by improving their financial institutions. LDCs, however, do not benefit from neither factor. Instead, trade liberalization seems to have the strongest impact on GDP growth in LDCs. Our findings suggest that LDCs, even more than investing in their human capital or improving their financial markets, should prioritize policies that ensure free trade.

A common characteristic of LDCs is their comparative advantage in labor-intensive production due to abondance of unskilled workers and relatively low wage rates. Trade openness in these countries is usually accompanied with an increase in demand for labor by international businesses, who are looking for lowering their production cost by hiring less expensive labor force. But as far as less developed countries are concerned, this reduces unemployment and increases wages, which improves the average income and quality of life. In addition to that, this makes a gradual spillover of technology possible, which also improves labor productivity and accelerates economic growth (Quah \& Rauch, 1990; Chuang, 1998).

Similarly, agricultural sectors that are typically large in LDCs as well as natural resources that require advanced technologies to extract will also benefit from international collaborations. Both of these changes provide the host country with significant sums of revenues that can be invested in welfare improving activities. Additionally, as Baltagi, Panicos, \& Siong Hook (2009) show trade openness, allowing free flow of goods, leads to financial development as well. Furthermore, open trade diversifies economy's supply sources, which lowers the economies sensitivity to sector-specific supply shocks. This, as a stabilizing force, reduces the level of uncertainty in the economy, which in turn improves economic growth (Madanizadeh \& Setayesh, 2020). These mechanisms explain why we find trade liberalization to be the most impactful strategy for achieving economic growth in LDCs. The remainder of this paper is organized as follows. Section 2 introduces the data. Section 3 explains the economic model. Section 4 reports our findings, and section 5 concludes. 


\section{Data}

We use national-level data for 164 countries listed in the appendix. Based on the world bank's classification, we categorize these countries into three groups of "Developed", "Developing", and "Less-developed" countries. In our sample, which runs from 1965 to 2017, there are 41 developed, 102 developing, and 21 less developed countries.

For our economic analysis, we use GDP per capita (constant 2005 USD) as reported by the World Development Indicators (WDI), the ratio of total liquid liabilities to the aggregate output (FD) as a proxy of financial development, which is reported by the International Financial Statistics (IFS) and the International Monetary Fund (IMF), Human Capital Index (HCI) as calculated by the Penn World Tables (PWT), and the ratio of sum of imports and exports to GDP (TL). Additionally, the ratio of government expenditures to the GDP (GOV), and the consumer price index $(2010=100)(C P I)$ are two control variables in our statistical model as they are commonly used in the literature. Table 1 reports mean and standard deviation of all variables for each income group.

Table 1. Summary Statistics

\begin{tabular}{|l|l|l|l|l|l|l|l|l|l|l|l|l|}
\hline & \multicolumn{3}{|l|}{ Output } & FD & \multicolumn{1}{l|}{ HCI } & \multicolumn{3}{l|}{ GOV } & \multicolumn{2}{l|}{ TL } & \multicolumn{2}{l|}{ CPI } \\
\cline { 2 - 14 } & Mean & s.d. & Mean & s.d. & Mean & s.d. & mean & s.d. & mean & s.d. & Mean & s.d. \\
\hline Developed & 10.01 & 0.73 & 4.09 & 0.68 & 2.81 & 0.50 & 0.16 & 0.05 & 0.79 & 0.69 & 3.36 & 2.95 \\
\hline Developing & 7.81 & 0.84 & 3.44 & 0.65 & 1.94 & 0.55 & 0.21 & 0.10 & 0.40 & 0.31 & 2.66 & 3.34 \\
\hline Less Developed & 6.25 & 0.51 & 2.83 & 0.99 & 1.36 & 0.37 & 0.19 & 0.11 & 0.23 & 0.19 & 2.10 & 5.31 \\
\hline
\end{tabular}

Source: See text.

Comparing three economic variables indicate that proxies for financial development, human capital, and trade liberalization, on average, rise with national income. This is consistent with economic theory that all three factors are growth-enhancing. Several studies have already investigated the statistical significance of this statement. In this paper, however, we are focused on finding factors that are relatively more impactful in LDCs.

An interesting pattern in LDCs in table 1 is that the standard deviation of trade openness is noticeably smaller among these countries compared to more developed ones, while the opposite is true about financial development. In other words, LDCs are uniformly less open to the world market. In addition, inflation has a larger variance in LDCs compared to the other two groups, which suggests some LDCs still suffer from high inflation rates.

\section{Economic Model}

As we discussed earlier, three important factors that are believed to affect output growth are human capital, financial development, and trade liberalization. The literature has studied their impacts from both a theoretical and empirical point of view. Though theoretically all these factors enhance economic growth, empirical investigations have led to ambiguous results. This paper aims to study whether the impacts of these factors vary with national income level of each country.

To conduct this analysis, we use a cross-country macro panel. Considering the non-stationary 
nature of most data series in macro panels, we start our analysis with statistical tests of stationarity. After establishing that all series are integrated of order one, we continue with panel cointegration tests that verify whether there is a long-run relationship between variables. Once that is approved, we conclude with estimating the coefficients of the long-run model. These coefficients are used to compare the relative impact of financial development, human capital, and trade liberalization on economic growth in each group of countries.

\subsection{Panel Unit Root Tests}

We conduct five residual-based panel unit root tests that are common in the literature on each series. These tests can be divided to two categories: (1) tests that allow for some form of heterogeneity across units, especially in the autoregressive parameters, and (2) tests that assume homogeneity in the data generating processes across all cross-section units of the panel. Specifications that consider different data generating processes across countries capture a wider range of non-stationarity in the data. The null hypothesis in all tests is that the series has a unit root.

In this study, for each series we conduct five different unit root tests that include Fisher-type tests, which are ADF (Maddala and Wu (2001)) and PP tests, as well as (Choi (2001)), Im, Pesaran \& Shin (2003), Levin, Lin \& Chu (2002), Breitung (2000). Among these tests, the first three consider individual unit root processes while the last two assume a common unit root process across all countries.

Table 2 reports the results of these tests. For each variable, the first column shows the test statistic for the variable itself while the second column is related to the test when it is performed on the first difference. Given the structure of these test, a statistically significant rejection of the null hypothesis implies stationarity. As it is seen in the table, our findings confirm that all series are not stationary at their levels, and that their first differences are stationary. Therefore, we can conclude that all series are integrated of order one, i.e. I(1).

Table 2. Panel Unit Root Tests

\begin{tabular}{|c|c|c|c|c|c|c|c|c|c|c|c|c|}
\hline & \multicolumn{2}{|c|}{ Output } & \multicolumn{2}{|c|}{ FD } & \multicolumn{2}{|c|}{ HCI } & \multicolumn{2}{|c|}{ GOV } & \multicolumn{2}{|c|}{ TL } & \multicolumn{2}{|c|}{ CPI } \\
\hline & Log & $\Delta \log$ & $\log$ & $\Delta \log$ & Log & $\Delta \log$ & Log & $\Delta \log$ & $\log$ & $\Delta \log$ & Log & $\Delta \log$ \\
\hline \multicolumn{13}{|c|}{ Developed Economies } \\
\hline Fisher-ADF & 18.32 & $-16.23^{* * * *}$ & 9.67 & $-26.10^{* * * *}$ & 2.59 & $-5.48^{* * *}$ & 3.41 & $-33.30^{* * * *}$ & 0.85 & $-30.24^{* * *}$ & 5.05 & $-7.11^{* * *}$ \\
\hline Fisher-PP & 24.72 & $-19.34^{* * *}$ & 0.88 & $-18.23^{* * *}$ & 9.39 & $-1.42^{*}$ & 3.60 & $-36.09^{* * * *}$ & 1.61 & $-35.69^{* * * *}$ & 17.52 & $-8.03^{* * *}$ \\
\hline IPS & 0.77 & $-20.14^{* * * *}$ & 0.26 & $-17.11^{* * *}$ & 1.40 & $-1.43^{*}$ & -0.71 & $-14.93^{* * *}$ & 1.23 & $-28.1^{* * *}$ & 16.35 & $-6.86^{* * *}$ \\
\hline LLC & -1.10 & $-21.03^{* * *}$ & 0.31 & $-12.96^{* * * *}$ & 4.75 & $-2.36^{* * *}$ & 1.09 & $-29.17^{* * *}$ & 4.87 & $-40.99^{* * *}$ & 3.39 & $-8.40^{* * *}$ \\
\hline Breitung & 4.89 & $-16.69^{* * * *}$ & -0.95 & $-9.43^{* * * *}$ & 3.38 & $-1.98^{* *}$ & 0.57 & $-10.8^{* * *}$ & -0.10 & $-12.94^{* * *}$ & 5.69 & $-8.83^{* * *}$ \\
\hline \multicolumn{13}{|c|}{ Developing Economies } \\
\hline Fisher-ADF & -4.98 & $-23.66^{* * *}$ & 1.07 & $-30.11^{* * *}$ & 9.60 & $-2.99^{* * * *}$ & 0.95 & $-50.04^{* * *}$ & 4.99 & $-58.09^{* * *}$ & 12.81 & $-14.07^{* * *}$ \\
\hline Fisher-PP & 0.85 & $-30.75^{* * *}$ & -1.14 & $-34.34^{* * *}$ & 9.36 & 1.39 & 1.15 & $-59.51^{* * *}$ & 4.85 & $-72.83^{* * *}$ & 23.49 & $-18.02^{* * *}$ \\
\hline IPS & 3.09 & $-29.29^{* * * *}$ & -0.42 & $-33.65^{* * *}$ & 3.31 & $-4.25^{* * *}$ & -2.11 & $-6.51^{* * *}$ & 0.05 & $-49.95^{* * *}$ & 2.49 & $-19.28^{* * * *}$ \\
\hline LLC & 18.95 & $-27.51^{* * *}$ & -1.26 & $-32.70^{* * * *}$ & 9.25 & -1.21 & 0.75 & $-38.91^{* * *}$ & 2.23 & $-31.00^{* * *}$ & 14.98 & $-26.59^{* * *}$ \\
\hline Breitung & 7.52 & $-16.45^{* * *}$ & 1.06 & $-24.82^{* * * *}$ & 0.54 & 0.72 & 0.53 & $-34.39^{* * * *}$ & 1.84 & $-19.40^{* * * *}$ & 2.64 & $-10.25^{* * *}$ \\
\hline \multicolumn{13}{|c|}{ Less Developed Economies } \\
\hline Fisher-ADF & 1.83 & $-14.02^{* * *}$ & 0.48 & $-14.86^{* * * *}$ & 4.21 & $-2.07^{* * * *}$ & -1.24 & $-15.98^{* * * *}$ & 1.48 & $-42.48^{* * * *}$ & -0.65 & $-8.54^{* * *}$ \\
\hline Fisher-PP & 3.23 & $-19.37^{* * *}$ & 0.32 & $-19.26^{* * *}$ & 8.54 & 1.32 & 0.72 & $-22.58^{* * *}$ & 0.99 & $-52.13^{* * *}$ & 2.53 & $-10.78^{* * *}$ \\
\hline IPS & 2.28 & $-18.26^{* * *}$ & 1.15 & $-14.70^{* * *}$ & 3.56 & $-2.78^{* * *}$ & 1.31 & $-14.39^{* * *}$ & 0.26 & $-21.1^{* * * *}$ & -1.23 & $-9.45^{* * *}$ \\
\hline LLC & 1.97 & $-18.12^{* * *}$ & -0.31 & $-13.14^{* * *}$ & 0.38 & 0.95 & 0.17 & $-14.91^{* * *}$ & 0.52 & $-21.38^{* * *}$ & -1.11 & $-10.54^{* * *}$ \\
\hline Breitung & 3.28 & $-9.17^{* * *}$ & -1.21 & $-9.64^{* * *}$ & 7.12 & $-5.57^{* * *}$ & 1.11 & $-9.17^{* * *}$ & -1.01 & $-12.86^{* * *}$ & 1.06 & $-8.55^{* * *}$ \\
\hline
\end{tabular}

Note: ${ }^{*}{ }^{* *}$, and ${ }^{* * *}$ denote significance at 10,5 , and 1 percent, respectively. 


\subsection{Co-integration Tests}

Panel cointegration tests are run to establish the existence of a long run relationship between all variables in the model. For this purpose, we conduct all seven Pedroni (2001) cointegration tests as the most common tests in the literature. It should be noted that our panels are macro panels consisting of country level data that are not systematically linked to each other. Therefore, the issue of cross-sectional dependence is less of a concern.

Pedroni (2001) provides some residual-based tests for the cointegration of panel variables. These tests basically extend unit root tests that are common in time series analysis to be applicable to the residuals of a regression equation in the panel structure. The null hypothesis of all of these tests is "no cointegration" among variables. Therefore, rejecting the null hypothesis implies the existence of a cointegration relationship. These tests vary in terms of the degree of heterogeneity that they allow among countries.

Table 3. Panel Co-integration Tests

\begin{tabular}{|l|l|l|l|}
\hline & Developed Countries & Developing Countries & Less Developed Countries \\
\hline Panel Specific Parameter & 0.99 & $-2.01^{* *}$ \\
\hline Modified PP-t & $5.56^{* * * *}$ & $1.63^{* *}$ & $-3.52^{* * *}$ \\
\hline PP-t & $4.48^{* * *}$ & $-11.49^{* * *}$ & $-7.11^{* * *}$ \\
\hline ADF-t & $3.58^{* * *}$ & \multicolumn{2}{|l|}{} \\
\hline Common Parameter & $1.71^{* *}$ & $4.04^{* * *}$ \\
\hline Modified v- ratio & $-1.73^{* *}$ & -0.82 \\
\hline Modified PP-t & $4.33^{* * *}$ & $2.32^{* * *}$ & $-2.46^{* * *}$ \\
\hline PP-t & $3.01^{* *}$ & $1.94^{* *}$ & $-1.96^{* *}$ \\
\hline ADF-t & $2.81^{* * *}$ & $2.31^{* *}$ & \\
\hline
\end{tabular}

Note: ${ }^{*}{ }^{* *}$, and ${ }^{* * *}$ denote significance at 10,5 , and 1 percent, respectively.

Similar to our categorization of unit root tests, we report Pedroni panel co-integration tests in two groups where within-dimension (panel specific) statistics allow for heterogeneous autoregressive parameters across countries while between-dimension (common parameter) statistics are constructed with the average of individual coefficients. Since there is no consensus as to which category captures cointegration relations more accurately, we report all test statistics for comparability.

Table 3 reports the results of Pedroni cointegration tests. To run these tests, the cointegrating vector was specified by including a panel-specific time trend. In addition to that, we used the Akaike Information Criterion (AIC) to determine the optimal number of lags to be included in the equation. As table 3 shows, our results strongly confirm that variables in all three panels are cointegrated approving the existence of a statistically meaningful long-term relationship between them. In the next section, we estimate the parameters of the cointegrating vectors.

\subsection{Long-run Relations}

The equation that we would like to estimate is a standard growth model that includes three economic factors and two control variables: 


$$
Y_{i t}=\alpha_{i}+\beta_{0} t+\beta_{1} F D_{i t}+\beta_{2} H C I_{i t}+\beta_{3} T L_{i t}+\beta_{4} G O V_{i t}+\beta_{5} C P I_{i t}+\varepsilon_{i t}
$$

In this equation $Y_{i t}$ represent per capita GDP of country $\mathrm{i}$ in year t. $F D_{i t}$ is the liquidity measure to proxy financial development, $H C I_{i t}$ shows the human capital index, and $T L_{i t}$ measures the degree of trade liberalization. Also, Gov $v_{i t}$, government size, which is measured by the ratio of governments' total expenditure to GDP, and $C P I_{i t}$, the consumer price index, are two control variables. In addition to these variables, country-specific intercepts and a time trend are also estimated in our cointegrating equations.

The cointegrating vector between variables is estimated by applying two widely used techniques: Fully Modified Ordinary Least Squares (FMOLS) and Dynamic Ordinary Least Squares (DOLS). Both of these methods improve upon the basic pooled OLS estimator by correcting for the biases that are caused by endogeneity in the panel. Consider the basic pooled OLS estimator, $\hat{\beta}_{\text {Pooled }}$, given by (2)

$$
\hat{\beta}_{\text {Pooled }}=\frac{\sum_{i=1}^{N} \sum_{t=1}^{T}\left(X_{i t}-\bar{X}\right)\left(Y_{i t}-\bar{Y}\right)}{\sum_{i=1}^{N} \sum_{t=1}^{T}\left(X_{i t}-\bar{X}\right)^{2}}
$$

where $Y_{i t}$ is the dependent variable, and $X_{i t}$ is the vector of all regressors.

Pedroni (2001) argues that differences in means among the individuals, which may lead to different responses to short-run disturbances from cointegrating equilibrium, are the main problem in estimating dynamic cointegrated panels. Therefore, his FMOLS method corrects for these biases. In order to do so, he includes individual specific intercepts in the main specification, and also allows for heterogeneity in the nature of serial correlation between error terms across units. The grouped-mean FMOLS estimator averages over the individual FMOLS estimates, and is given by

$$
\hat{\beta}_{F M O L S}=\frac{1}{N} \frac{\sum_{i=1}^{N} \sum_{t=1}^{T}\left(X_{i t}-\bar{X}\right) Y_{i t}^{*}-T \widehat{\tau}_{l}}{\sum_{i=1}^{N} \sum_{t=1}^{T}\left(X_{i t}-\bar{X}\right)^{2}}
$$

where $Y_{i t}^{*}=\left(Y_{i t}-\bar{Y}_{l}\right)-\frac{\hat{L}_{21 i}}{\hat{L}_{22 i}} \Delta X_{i t}$, and $\hat{\tau}_{i}=\hat{\Gamma}_{21 i}+\Omega_{21 i}^{0}-\frac{\hat{L}_{21 i}}{\hat{L}_{22 i}}\left(\widehat{\Gamma}_{21 i}-\Omega_{22 i}^{0}\right)$.

Consider the regression equation $Y_{i t}=\alpha_{i}+\beta X_{i t}+\varepsilon_{i t}$, and a dynamic relationship between regressors $X_{i t}=X_{i, t-1}+\mu_{i t}$. Based on error terms of these two equations, the composite covariance matrix $\Omega_{i}$ is defined as

$$
\Omega_{i}=\left[\begin{array}{ll}
\Omega_{11 i} & \Omega_{12 i} \\
\Omega_{21 i} & \Omega_{22 i}
\end{array}\right]
$$

Where the diagonal terms represent long-run variances of $\varepsilon_{i t}$, and $\mu_{i t}$, respectively. Off-diagonal terms of this symmetric matrix are the long-run covariance between these two terms. $\Omega_{i}$ may be decomposed to the sum of a contemporaneous term, $\Omega_{i}^{0}$, and a dynamic covariance term, $\hat{\Gamma}_{i}$. In other words, $\Omega_{i}=\Omega_{i}^{0}+\Gamma_{i}+\Gamma_{i}^{\prime}$. Lastly, following Pedroni (2000), $L_{i}$ denotes the lower triangular matrix of a triangularization of the $\Omega_{i}$ matrix. 
Table 4. FMOLS and DOLS estimators

\begin{tabular}{|c|c|c|c|c|c|c|c|c|c|c|}
\hline & \multicolumn{5}{|c|}{ FMOLS Estimation } & \multicolumn{5}{|c|}{ DOLS Estimation } \\
\hline & FD & HCI & TL & GOV & CPI & FD & HCI & TL & GOV & CPI \\
\hline Developed Countries & $\begin{array}{l}0.015 \\
(0.020) \\
\end{array}$ & $\begin{array}{l}1.031^{* * *} \\
(0.033)\end{array}$ & $\begin{array}{l}0.178^{* * *} \\
(0.026) \\
\end{array}$ & $\begin{array}{l}-1.568^{* * * *} \\
(0.199)\end{array}$ & $\begin{array}{l}-0.012^{* * * *} \\
(0.003)\end{array}$ & $\begin{array}{l}-0.08^{* * * *} \\
(0.024)\end{array}$ & $\begin{array}{l}1.07 \text { *** } \\
(0.039) \\
\end{array}$ & $\begin{array}{l}0.223 * * * \\
(0.027)\end{array}$ & $\begin{array}{l}-0.756 * * * \\
(0.256) \\
\end{array}$ & $\begin{array}{l}-0.015^{* * * *} \\
(0.002)\end{array}$ \\
\hline Developing Countries & $\begin{array}{l}0.235^{* * *} \\
(0.025)\end{array}$ & $\begin{array}{l}0.630^{* * *} \\
(0.037) \\
\end{array}$ & $\begin{array}{l}0.299^{* * * *} \\
(0.054) \\
\end{array}$ & $\begin{array}{l}-0.261^{* *} \\
(0.120) \\
\end{array}$ & $\begin{array}{l}-0.017^{* * * *} \\
(0.004) \\
\end{array}$ & $\begin{array}{l}0.215 * * * \\
(0.035) \\
\end{array}$ & $\begin{array}{l}0.707 \text { *** } \\
(0.044)\end{array}$ & $\begin{array}{l}0.157 * * \\
(0.065)\end{array}$ & $\begin{array}{l}0.004 \\
(0.174) \\
\end{array}$ & $\begin{array}{l}-0.016 \text { *** } \\
(0.003)\end{array}$ \\
\hline Less Developed Countries & $\begin{array}{l}-0.011 \\
(0.021) \\
\end{array}$ & $\begin{array}{l}0.453^{* * *} \\
(0.117)\end{array}$ & $\begin{array}{l}0.544^{* * *} \\
(0.120)\end{array}$ & $\begin{array}{l}0.222 \\
(0.167) \\
\end{array}$ & $\begin{array}{l}-0.034^{* * * *} \\
(0.011)\end{array}$ & $\begin{array}{l}0.105^{* * *} \\
(0.022)\end{array}$ & $\begin{array}{l}0.130 \\
(0.133) \\
\end{array}$ & $\begin{array}{l}0.507 * * * \\
(0.109) \\
\end{array}$ & $\begin{array}{l}-0.028 \\
(0.170) \\
\end{array}$ & $\begin{array}{l}-0.064 * * * \\
(0.013)\end{array}$ \\
\hline
\end{tabular}

Note: numbers in parenthesis are standard errors. ${ }^{*},{ }^{* *}$, and ${ }^{* * *}$ denote significance at 10,5 , and 1 percent, respectively.

In contrast, Kao and Chiang (2000) propose the pooled DOLS estimator which uses ordinary least squares to estimate a cointegrating regression equation that is augmented with leads and lags of the first difference of independent variables.

$$
Y_{i t}=\alpha_{i}+\beta X_{i t}+\sum_{j=-p_{i}}^{q_{i}} \Delta X_{i, t+j}+\varepsilon_{i t}
$$

where $p_{i}$ and $q_{i}$ are country-specific numbers of lags and leads, which in this paper we determine using the AIC criterion. Kao and Chiang (2000) argue that DOLS estimator, compared to FMOLS has better finite sample properties. Nevertheless, we report both estimations in each group of countries. Table 4 reports the FMOLS and DOLS estimators for each panel of countries separately. Both estimates are pooled estimators that include a deterministic trend in their cointegrating vectors. As mentioned earlier, leads and lags in DOLS estimations were determined using the AIC criterion.

\section{Results}

Our findings based on estimations that are reported in table 4, are as follows. Overall impacts of all variables are consistent with economic theory. However, the heterogeneity of our findings across three groups are noticeable. In particular, developed economies seem to benefit the most from human capital while financial development does not stimulate output in these countries. The exact opposite is true about developing economies where financial development is significantly more powerful than human capital. These results are consistent with Mohaghegh and Valipour (2020).

An important finding of this paper is that trade liberalization, though growth-enhancing in all groups, is exceptionally effective in LDCs. In other words, LDCs would benefit the most from promoting trade openness in their economies. Several mechanisms have been proposed to explain how trade liberalization could be particularly growth enhancing in LDCs which we discuss below.

First, LDCs feature abundance of unskilled workers who are willing to work at lower wage rates than those in developed economies. That results in a comparative advantage of LDCS in 
labor-intensive sectors. Trade liberalization enables international businesses to move their production lines to less developed countries. This not only lowers the production cost for producers, but it also increases labor demand in the host economy, which in turn, reduces unemployment, increases wage rates, and improves an average worker's income and standard of living.

Besides, international trade typically leads to a gradual spillover of technology to LDCs, and improves the skillset of workers through learning-by-doing. Workers benefit from both of these effects in the long-run (Chuang, 1998). Moreover, this process improves the average level of human capital in the economy which itself accelerates economic growth (Quah \& Rauch, 1990).

Second, LDCs feature abundance of unused (or inefficiently used) land which can be used in agriculture. Trade liberalization typically improves agricultural productivity in those countries as it leads to the import of capital and modern machinery. This, in turn, benefits both the investors and local workers. This channel also improves human capital and amplifies growth in the host country.

Third, international investors can invest in the extraction of natural resources in LDCs. These sectors usually lack the capital and technology needed for optimal use. Therefore, trade openness could generate considerable revenue for the host country. The effectiveness of this mechanism critically depends on (1) efficient contracting between the host country and international businesses and (2) efficient distribution of generated revenues across sectors and households. This is what separates the third channel from the first two. The other mechanisms work under the free market principle and, thus, incentive compatibly distribute profits among parties. Whether the revenues earned from natural resource extraction surpasses the inefficiencies associated with optimal use of these funds is, however, beyond the subject of this study.

Fourth, Baltagi, Panicos, \& Siong Hook (2009) study the interaction of financial openness, which allows a free flow of capital, and trade openness, which allows a free flow of goods. They show that both types of openness boost financial development. It should be noted that the effectiveness of mechanisms that we discuss here rely on both notions of openness. In fact, these two concepts amplify each other's impacts.

Lastly, trade openness diversifies economy's supply sources. Therefore, the economy will be less sensitive to sector-specific supply shocks as diversifiable shocks will be cancelled out through international flows of goods and capital. This effectively reduces the level of uncertainty that economic agents face, and as shown by Madanizadeh \& Setayesh (2020) further improves economic development. These mechanisms explain why trade liberalization is found to have the strongest impact on economic growth in LDCs.

Also, our findings confirm that rises in the size of governments or in nominal prices almost invariably negatively affect economic growth. Despite overall trends, different groups respond differently to these two factors as well. The size of government appears to be far more threatening in developed economies while inflation is more damaging in LDCs. These 
findings are robust across both methods of estimation.

\section{Conclusion}

This paper determines macroeconomic policies that strongly stimulate less-developed countries' economic growth. We study the heterogeneous impacts of financial development, human capital, and trade openness in different development stages. Though, all these factors are proven to be growth-enhancing, the cross-country empirical results are mixed and inconclusive. We use data from a panel of more than 160 countries and divide these countries to three panels of developed, developing, and less developed. We use non-stationary panel data estimation techniques to compare the quantitative effects of these factors in each panel. Our premise is that these effects vary over different stages of economic development. Hence, we expect the relative coefficients of human capital, financial development, and trade liberalization to be different across panels.

Panel unit root tests show that all series are integrated of order one in all panels. Also, Pedroni's cointegration tests strongly support the idea that there is a long-term relationship between output and three main factors in all panels. We show the most effective factor in economic growth in less-developed countries is neither financial development not human capital growth. In fact, these two factors do not significantly contribute to the economic growth of these countries. We instead show that trade liberalization is the most effective factor in eliminating poverty and boosting economic growth.

We summarize our findings in two statements: (1) Financial development, human capital, and trade openness all positively influence output growth in all countries. However, their quantitative impacts vary with national income level. This, in addition to important policy implications, explains mixed and inconclusive findings of empirical studies in the literature. (2) We establish that in less-developed countries trade liberalization is the most effective tool to achieve economic growth.

\section{References}

Acemoglu, D. (1996). A Microfoundation for Social Increasing Returns in Human Capital Accumulation. Quarterly Journal of Economics, 111(3), 779-804.

https://doi.org/10.2307/2946672

Aghion, P., \& Howitt, P. (1992). A Model of Growth Through Creative Destruction. Econometrica, 60(2), 323-351. https://doi.org/10.2307/2951599

Baltagi, B. H., Panicos, O. D., \& Siong Hook, L. (2009). Financial development and openness: Evidence from panel data. Journal of Development Economics, 89(2), 285-296. https://doi.org/10.1016/j.jdeveco.2008.06.006

Barro, R. J. (1991). Economic Growth in a Cross Section of Countries. Quarterly Journal of Economics, 106(2), 407-443. https://doi.org/10.2307/2937943

Benhabib, J., \& Spiegel, M. M. (1994). The role of human capital in economic development evidence from aggregate cross-country data. Journal of Monetary Economics, 34(2), 143-173. 
https://doi.org/10.1016/0304-3932(94)90047-7

Bils, M., \& Klenow, P. J. (2000). Does schooling cause growth? American Economic Review, 90(5), 1160-1183. https://doi.org/10.1257/aer.90.5.1160

Breitung, J. (2000). The Local Power of Some Unit Root Tests for Panel Data. (B. F. Baltagi, Ed.) Advances in Econometrics, 15, 161-177.

https://doi.org/10.1016/S0731-9053(00)15006-6

Cadil, J., Petkovova, L., \& Blantna, D. (2014). Human Capital, Economic Structure and Growth. Procedia Economics and Finance, 12, 85-92.

https://doi.org/10.1016/S2212-5671(14)00323-2

Choi, I. (2001). Unit root tests for panel data. Journal of International Money and Finance, 20(2), 249-272. https://doi.org/10.1016/S0261-5606(00)00048-6

Chuang, Y.-C. (1998). Learning by doing, the technology gap, and growth. International Economic Review, 39(3), 697-721. https://doi.org/10.2307/2527396

Devereux, M. B., \& Lapham, B. J. (1994). The Stability of Economic Integration and Endogenous Growth. Quarterly Journal of Economics, 109(1), 299-305.

https://doi.org/10.2307/2118436

Ductor, L., \& Grechyna, D. (2015). Financial development, real sector, and economic growth. International Review of Economics \& Finance, 37(C), 393-405.

https://doi.org/10.1016/j.iref.2015.01.001

Fama, E. F. (1985). What's different about banks? Journal of monetary economics, 15(1), 29-39. https://doi.org/10.1016/0304-3932(85)90051-0

Hall, R. E., \& Jones, C. I. (1999). Why do some countries produce so much more output per worker than others? The Quarterly Journal of Economics, 114(1), 83-116.

https://doi.org/10.1162/003355399555954

Hassan, M. K., Sanchez, B., \& Yu, J.-S. (2011). Financial development and economic growth: New evidence from panel data. The Quarterly Review of Economics and Finance, 51(1), 88-104. https://doi.org/10.1016/j.qref.2010.09.001

Im, K. S., Pesaran, M., \& Shin, Y. (2003). Testing for unit roots in heterogeneous panels. Journal of Econometrics, 115(1), 53-74. https://doi.org/10.1016/S0304-4076(03)00092-7

Kao, C., \& Chiang, M. (2000). On the estimation and inference of a cointegrated regression in panel data. Advances in Econometrics, 15, 179-222.

https://doi.org/10.1016/S0731-9053(00)15007-8

King, R., \& Levine, R. (1993). Finance and Growth: Schumpeter Might Be Right. Quarterly Journal of Economics, 108, 717-737. https://doi.org/10.2307/2118406

Law, S. H., \& Singh, N. (2014). Does too much finance harm economic growth? Journal of Banking \& Finance, 41, 36-44. https://doi.org/10.1016/j.jbankfin.2013.12.020 


\section{Macrothink}

Business and Economic Research ISSN 2162-4860 2021, Vol. 11, No. 2

Levin, A., Lin, C. F., \& Chu, J. C. (2002). Unit root tests in panel data: asymptotic and finite-sample properties. Journal of Econometrics, 108(1), 1-24.

https://doi.org/10.1016/S0304-4076(01)00098-7

Levine, R. (1997). Financial Development And Economic Growth: Views And Agenda. Journal of Economic Literature, 305, 688-726.

Levine, R., Loayza, N., \& Beck, T. (2000). Financial intermediation and growth: Causality and causes. Journal of Monetary Economics, 46(1), 31-77.

https://doi.org/10.1016/S0304-3932(00)00017-9

Madanizadeh, S., \& Setayesh, A. (2020). Macroeconomic uncertainty and economic development. Working paper.

Maddala, G. S., \& Wu, S. (2001). A comparative study of unit root tests with panel data and a new simple test. Oxford Bulletin of Economics and Statistics, 61(s1), 631-652.

https://doi.org/10.1111/1468-0084.61.s1.13

Mankiw, G. N., Romer, D., \& Weil, D. N. (1992). A Contribution to the Empirics of Economic Growth. Quarterly Journal of Economics, 107(2), 407-437.

https://doi.org/10.2307/2118477

McKinnon, R. I. (1973). Money and Capital in Economic Development. Washington D.C.: Brookings Institution.

Mohaddes, K., \& Pesaran, M. H. (2013). One hundred years of oil income and the Iranian economy: A curse or a blessing? Iran and the Global Economy, 28-61.

https://doi.org/10.4324/9781315867205-9

Mohaghegh, M., \& Valipour, A. (2020). Income-dependent Imapcs of Financial Development and Human Capital on Economic Growth: A Non-stationary Panel Analysis. Theoretical and Applied Economics, 27(625), 263-274.

Narayan, P. K., \& Narayan, S. (2013). The short-run relationship between the financial system and economic growth: New evidence from regional panels. International Review of Financial Analysis, 29, 70-78. https://doi.org/10.1016/j.irfa.2013.03.012

Pedroni, P. (2000). Fully Modified OLS for Heterogeneous Cointegrated Panels. Working Papers No 2000-03. https://doi.org/10.1016/S0731-9053(00)15004-2

Pedroni, P. (2001). Critical values for cointegration tests in heterogeneous panels with multiple regressors. Oxford Bulletin of Economics and Statistics, 653-670.

https://doi.org/10.1111/1468-0084.61.s1.14

Quah, D., \& Rauch, J. (1990). Openness and the rate of economic growth.

Rivera-Batiz, L. A., \& Romer, P. M. (1991). Economic Integration and Endogenous Growth . Quarterly Journal of Economics, 106(2), 531-555. https://doi.org/10.2307/2937946

Rodriguez, F., \& Rodrik, D. (1999). Trade Policy and Economic Growth: A Skeptic's Guide 


\section{Macrothink \\ Business and Economic Research \\ ISSN 2162-4860 \\ 2021, Vol. 11, No. 2}

to Cross-National Evidence. NBER Working Paper Series, w7081.

https://doi.org/10.3386/w7081

Rogers, M. (2008). Directly Unproductive Schooling: How Country Characteristics Affect the Impact of Schooling on Growth. European Economic Review, 52(2), 356-385.

https://doi.org/10.1016/j.euroecorev.2007.03.001

Romer, P. M. (1990). Endogenous technological change. Journal of political Economy, 98(5), 71-102. https://doi.org/10.1086/261725

Shaker-Akhtekhane, S. (2019). Entry Barriers in a Two-Sector economy with Perfect and Imperfect Financial Markets. Working Paper.

Shaker-Akhtekhane, S. (2020). Impact of Entry Costs on Aggregate Productivity: Financial Development Matters. Working Paper.

Shaw, E. S. (1973). Financial Deepening in Economic Development. New York: Oxford University Press.

Singh, A. (1997). Financial liberalization, stock markets and economic development. Economic Journal, 107(442), 771-782. https://doi.org/10.1111/j.1468-0297.1997.tb00042.x

Wacziarg, R., \& Welch, H. K. (2008). Trade Liberalization and Growth: New Evidence. The World Bank Economic Review, 22(2), 187-231. https://doi.org/10.1093/wber/lhn007

\section{Notes}

Note 1. (Mohaghegh \& Valipour, 2020) have shown the impact of human capital growth on economic growth in developed countries is more than that in developing countries. On the other side, the impact of financial development on economic growth is more pronounced in developing countries.

\section{Appendix}

Table 5 shows our country classification throughout this study. It is based on World Bank's income classification. 
Table 5. List of Countries

\begin{tabular}{|c|c|c|c|c|}
\hline \multirow{2}{*}{$\begin{array}{l}\text { Developed } \\
\text { Aroentina }\end{array}$} & \multicolumn{3}{|l|}{ Developing } & \multirow{2}{*}{$\begin{array}{l}\text { Less developed } \\
\text { Burundi }\end{array}$} \\
\hline & Angola & Kyrgyz Republic & Tonga & \\
\hline Australia & Albania & Cambodia & Tunisia & Benin \\
\hline Austria & Armenia & Kiribati & Turkey & Burkina Faso \\
\hline Belgium & Azerbaijan & Lao PDR & Tuvalu & Central African Republic \\
\hline Bahrain & Bangladesh & Lebanon & Ukraine & Congo, Dem. Rep. \\
\hline Barbados & Bulgaria & Libya & Uzbekistan & Ethiopia \\
\hline Canada & Belarus & St. Lucia & St. Vincent and the Grenadines & Gambia, The \\
\hline Switzerland & Bosnia and & Sri Lanka & Venezuela, RB & Haiti \\
\hline Chile & Herzegovina & Lesotho & Vietnam & Liberia \\
\hline Cyprus & Belize & Morocco & Vanuatu & Madagascar \\
\hline Germany & Bolivia & Moldova & Samoa & Mali \\
\hline Denmark & Brazil & Maldives & Kosovo & Mozambique \\
\hline Spain & Bhutan & Mexico & South Africa & Malawi \\
\hline Finland & Botswana & Marshall Islands & Zambia & Niger \\
\hline France & China & North Macedonia & & Nepal \\
\hline United Kingdom & Côte d'Ivoire & Myanmar & & Rwanda \\
\hline Greece & Cameroon & Montenegro & & Senegal \\
\hline Hong Kong SAR, China & Congo, Rep. & Mongolia & & Sierra Leone \\
\hline Hungary & Colombia & Mauritania & & Togo \\
\hline Ireland & Cabo Verde & Mauritius & & Tajikistan \\
\hline Iceland & Costa Rica & Malaysia & & Tanzania \\
\hline Israel & Cuba & Namibia & & Uganda \\
\hline Italy & Djibouti & Nigeria & & Yemen, Rep. \\
\hline Japan & Dominica & Nicaragua & & Zimbabwe \\
\hline Korea, Rep. & Dominican Republic & Nauru & & \\
\hline Luxembourg & Algeria & Pakistan & & \\
\hline Macao SAR, China & Ecuador & Peru & & \\
\hline Malta & Egypt, Arab Rep. & Philippines & & \\
\hline Netherlands & Fiji & Papua New Guinea & & \\
\hline Norway & Micronesia, Fed. & Paraguay & & \\
\hline New Zealand & Gabon & West Bank and Gaza & & \\
\hline Panama & Georgia & Romania & & \\
\hline Poland & Ghana & Russian Federation & & \\
\hline Portugal & Equatorial Guinea & Sudan & & \\
\hline Saudi Arabia & Grenada & Solomon Islands & & \\
\hline Singapore & Guatemala & El Salvador & & \\
\hline Slovenia & Guyana & Serbia & & \\
\hline Sweden & Honduras & São Tomé and Principe & & \\
\hline Trinidad and Tobago & Indonesia & Suriname & & \\
\hline Uruguay & India & Eswatini & & \\
\hline United States & Iran, Islamic Rep. & Thailand & & \\
\hline & Iraq & Turkmenistan & & \\
\hline & Jamaica & Timor-Leste & & \\
\hline & Jordan & & & \\
\hline & Kazakhstan & & & \\
\hline & Kenya & & & \\
\hline
\end{tabular}

\section{Copyright Disclaimer}

Copyright for this article is retained by the author(s), with first publication rights granted to the journal.

This is an open-access article distributed under the terms and conditions of the Creative Commons Attribution license (http://creativecommons.org/licenses/by/4.0/). 